\title{
TRANSKRIPTIOSTA SÄHKÖKITARAMUSIIKIN TUTKIMUKSESSA
}

Tässä artikkelissa tarkastelen joitakin transkriptioihin liittyviä keskeisiä ongelmia, jotka tulevat esille sähkökitaramusiikin tutkimuksessa. Lukuisista ongelmista keskeisimpiä ovat äänenvärin kuvaamiseen ja notaatiomerkintöihin liittyvät vaikeudet. Seuraavassa esitän ongelmakentän kuvaamisen jälkeen omat ehdotukseni transkriptiomerkinnöiksi. Lähtökohdan ehdotuksilleni muodostavat toisaalta Mantle Hoodin organologiassa esitetyt symbolit ja toisaalta yleisessä käytössä olevat notaatiomerkinnät. Esiteltyjen transkriptiomerkintöjen soveltuvuutta tarkastelen kolmessa transkriptiossa, jotka olen tehnyt Jimi Hendrixin kitarasooloista. Esitykseni perustuu pääosin Hendrixiä käsittelevään pro gradu -tutkielmaani (Savola 1989), ja siksi rockmusiikki ja Hendrix sen keskeisimpänä vaikuttajahahmona muodostavat viitekehyksen artikkelilleni.

\section{Ongelmakenttä}

Sähkökitara on instrumenttina erittäin monipuolinen ja sen laaja sointiväriasteikko on erilaisten soittotapojen, lisälaitteiden ja koko ajan nopeasti kehittyvän studiotekniikan tarjoamien sovellutusmahdollisuuksien ansiosta haastava ja vaikeakin tutkimuskohde. Rockmusiikille olennais- 
ten sointuvärien ja niiden muutosten sekä sähkökitaran erilaisten soittotapojen merkitseminen vaatii usein mielikuvitusta, koska ei ole olemassa vakiintuneita notaatiotapoja. Joidenkin merkintöjen suhteen on kuitenkin olemassa jossakin määrin yhteneväistä käytäntöä. Koska sointivärin kuvaaminen on usein vaikein ongelma transkriptioiden tekijälle, seuraavassa tarkastellaan joitakin sointivärin kuvaamisen kannalta keskeisiä tekijöitä.

Rockmusiikin sointivärimaailman ymmärtämisen kannalta on syytä aluksi lyhyesti tarkastella äänitystekniikan kehitystä. Studiotekniikan kehityksen myötähän on tullut entistä helpommaksi esimerkiksi yhdistää ääninauhalle yhä useampia soittimia sekä useiden päällekkäisäänitysten avulla muunnella soittimien äänenväriä.

Emblidge $(1973,20)$ on esittänyt äänitystekniikan kehitysvaiheet 1950-luvulta 1970-luvulle asti. Hänen mukaansa 1950-luvun puoliväliin saakka äänitykset tehtiin monoäänityksinä eli yhdelle ääniraidalle. Vuodesta 1956 lähtien käyttöön alkoi tulla jo kaksi ja neljä ääniraitaa. Neliraitainen äänitystekniikka mahdollisti jo paremmin päällekkäisäänitykset. Ensimmäiset stereolevytykset julkaistiin vuonna 1958, ja vuonna 1963 kehitettiin musiikkikasetti. 1960-luvun puolivälissä neliraitainen äänitystekniikka oli jo vakiintumassa yleiseen käyttöön. 1960-luvun loppu-puolella 8-raitatekniikka oli jo yleistymässä. 1970-luvun alkupuolella 16-raitainen äänitystekniikka alkoi olla jo vakiona. (Ks. myös Sandner 1977, 6; Brolinson ja Larsen 1981, 148; Emblidge 1973, 130.) Jos ajatellaan Hendrixin levytyksiä, niin levyt Are You Experienced (1967) ja Axis: Bold As Love (1968) on tehty 4-raitatekniikalla ja niitä seurannut Electric Ladyland (1968) on tehty 8-raitatekniikalla. Vuonna 1970 valmistuneessa Electric Ladyland -studiossaan Hendrixillä oli käytössään jo 32-raitainen äänitystekniikka. (Menn 1978, 91 ja 96; Henderson 1983, 219; Knight 1975, 155.)

1960-luvun loppupuolelta lähtien erilaiset soittimien yhteydessä käytettävät lisälaitteet tulivat yhteiseen käyttöön muusikoiden parissa, ja ne mahdollistivat sointivärien helpomman muuntelun niin studioissa kuin konserteissakin. Esimerkiksi wah-wah-pedaali ilmestyi markkinoille Hendrixin ensimmäisen kiertueen aikana eli vuonna 1967 (Menn 1978, 96). Sähkökitaran sointiväriä voidaan lisälaitteiden lisäksi muunnella tietenkin myös erilaisilla soittotekniikoilla ja studiotekniikan suomilla sovellutusmahdollisuuksilla. Schneider $(1985,74)$ on kuvannut sähkökitaran muuttuvia vakioita ja niiden muuttamiseen käytettyjä tekniikoita seuraavalla kaaviolla (kuva 1): 


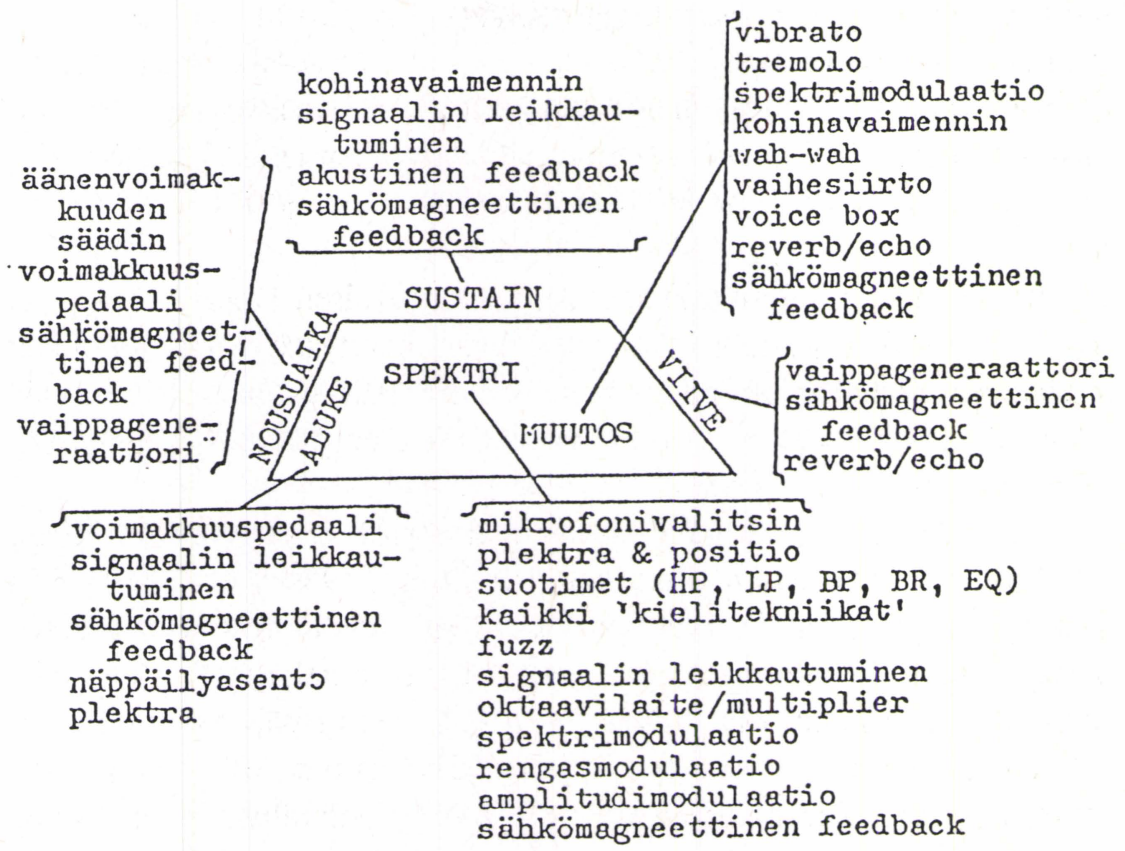

Akustisella feedbackilla Schneider tarkoittaa sitä äänen kiertoilmiötä, joka syntyy sähkökitaran mikrofonien ja kaiuttimien välille; sähkömagneettinen feedback syntyy, kun kitaran kieliä soitetaan kädessä pidettävällä laitteella, jonka toiminta perustuu sähkömagneettiseen ilmiöön - tällainen laite on esimerkiksi E-bow.

Schneiderin kaavion pohjalta voi todeta, että sähkökitara muodostaa sointivärien ja niiden aikaansaamiseksi käytettyjen soittotekniikoiden kuvaamisen kannalta todella moni-ilmeisen kohteen niin tutkijalle kuin transkriptioiden tekijällekin. Kaavion yksityiskohtainen tarkastelu ei ole tässä yhteydessä tarpeen: ongelmien lukuisuuden ymmärtämiseksi riittää, kun todetaan, että monille kaaviossa mainituille tekniikoille ei ole olemassa merkintätapaa ja että joidenkin yleisesti käytössä olevien notaatiotapojen käyttö on kirjavaa ja vakiintumatonta. 


\section{Hoodin organologiasta}

Hood (1982, xxi-xxiii) on esittänyt omassa soitinten luokittelujärjestelmässään eli organologiassaan kategorian myös sähkön avulla tuotetuille tai muunnelluille äänille ja soittimille. Hoodin mukaan elektronofonien luokkaa voidaan soveltaa käytettäväksi seuraaviin instrumentteihin ja äänien tuottamiseksi kehitettyihin laitteisiin: (1) varhaiset yksilölliset soittimet, joita alettiin kehittää 1920-luvulta lähtien; näitä ovat esimerkiksi Tratonium, ondes Martenot, Theremin, Hammond-urut, sähköinen carillon ja sähköiset kirkonkellot, (2) sähkökomponenteista kootut laitteet, jotka on suunniteltu tuottamaan tai muuntamaan ääniä siten, että tuloksena on musiikillisesti hyväksyttävä ääni; tällainen laite on esimerkiksi Mini-Moog, sekä (3) perinteisten soittimien modifikaatiot, jotka perustuvat sähköisesti vahvistettuihin ääniin; tällaisia modifikaatioita ovat esimerkiksi sähkö- ja pedal steel -kitara. Hoodin elektronofonien perussymboli eli organogrammi (organogram) on isokokoinen johon voidaan tarvittaessa liittää pienempiä lisäsymboleja. Ääntä tuottavien ja käsittelevien laitteiden symbolit Hood ehdottaa sijoitettavaksi perussymbolien vasemmalle puolelle ja ääntä kontrolloivien laitteiden symbolit perussymbolien oikealle puolelle. (Hood käyttää käsitettä rockkitara (rock guitar), joka on kuitenkin liian epämääräinen käsite, ja tästä syystä se on tässä yhteydessä korvattu tarkemmalla sähkökitaran käsitteellä. Hood on esimerkkinä kuvannut Mini-Moogin symbolien avulla, mutta se on tässä yhteydessä liian monimutkainen esitettäväksi selityksineen (ks. tarkemmin Hood 1982, xxiii)).

Sähkökitaran Hood esittää kuvattavaksi symbolien avulla seuraavasti:

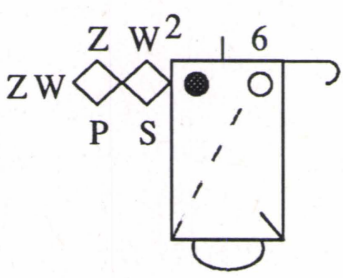

Esitetty sähkökitaran kuvaus perustuu kordofonien perussymboliin, $\square$ jøhon on liitetty erilaisia lisäsymboleja: 6 kuvaa kuusikielistä luuttua; $;$ kuvaa kitaran diagonaalista soittoasentoa; 9 kuvaa 
soittajaa

- soittamassa kitaraa yhdellä tai useammalla plektralla oikeassa kädessään vasemman käden $\longrightarrow$ hoitaessa sormitukset; kuvaa kitaran kantohihnaa. Pienikokoinen $\diamond$ tarkoittaa, että instrumentti on modifioitu sähköiseksi perinteisemmästä soittimesta. S tarkoittaa, että perinteisimmän, tässä tapauksessa akustisen kitaran, laatikkomallinen kaikupohja on korvattu kiinteällä rungolla (solid body). Lisälaitteet on merkitty seuraavasti: $\mathrm{W}^{2}=$ wah-wah, $\mathrm{Z}=$ fuzz, $\mathrm{ZW}=$ fuzz-wah ja $\mathrm{P}=$ phaser. Hoodin esittämä lisälaitteiden yhdistelmä on vain yksi esimerkki lisälaitteiden yhdistelmästä. Jokaisella kitaristilla on yleensä oma suosikkiyhdistelmänsä, ja usein myös tyylisuunta saattaa edellyttää tietynlaista lisälaitteiden yhdistelmää - tai niiden hylkäämistä kokonaan.

Sovellutus ja ehdotukset transkriptiomerkinnöiksi

Hendrixiin sovellettuna Hoodin esittämien symbolien avulla saadaan kuvio, jossa Hendrixin käyttämien lisälaitteiden symbolien selitykset ovat seuraavat: $\mathrm{F}=$ fuzz, $\mathrm{W}$ = wah-wah ja $\mathrm{U}=$ univibe (Leslie-tyyppinen lisälaite), jota Hendrix käytti joskus uransa loppuvaiheilla.

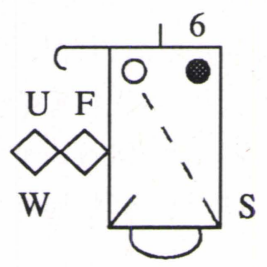

Hoodista poiketen olen siis Z:n tilalla käyttänyt mielestäni loogisempaa ja selvempää lyhennettä $F$, ja $W^{2}$ :n tilalla olen käyttänyt mielestäni riittävää lyhennettä W. S on sijoitettu sekaannusten välttämiseksi rungon toiselle puolelle, sillä sehän ei ole lisälaitteen, vaan kiinteän rungon symboli. Esitetystä kuvauksesta on syytä huomata, että Hendrix soitti vasenkätisenä kitaraa siten, että plektra oli tietenkin vasemmassa kädessä. Joskus hän soitti lyhyitä jaksoja myös ilman plektraa eli pelkästään plektrakäden sormilla tai sormittavan käden sormilla. Tämä käy ilmi esimerkiksi Nealin (1968) ja Wein (1970) ohjaamista elokuvista.

Hoodin esittämille symboleille perustuvaa kuvaustapaa voidaan melko yksiselitteisesti soveltaa sähkökitaran kuvaamiseen soittimena. Hood 
on esittänyt myös lukuisia lisäsymboleja, joilla voidaan selventää eri soittimiin ja niiden soittotekniikoihin liittyviä yksityiskohtia. (Ks. Hood 1982, xxii, xxv, 162 ja 166.)

Seuraavassa esiteltävät ehdotukseni transkriptiomerkinnöiksi on jaoteltu neljään osa-alueeseen, jotka ovat seuraavat: (1) viritys, (2) soundi, (3) erilaiset soittotekniikat ja (4) muut merkinnät. Näistä osaalueistani on todettava, että soundin osalta merkintäni perustuvat Hoodin perussymboleille - numerointi on omani - ja että soittotekniikoiden osalta merkintäni perustuvat osin yleisessä käytössä olevilla merkintätavoille. Ehdotukseni transkriptiomerkinnöiksi ovat täten seuraavat:

(1) viritys:

$$
\text { \& = normaaliin säveltasoon viritetty kitara - transkriptio in C. }
$$

in $\mathrm{C}$

\& = noin $1 / 2$-sävelaskelta normaalia säveltasoa matalampi viritys.

Soiva säveltaso on siis noin $1 / 2$-sävelaskelta matalampi kuin mitä in $\mathrm{H}$ kirjoitettu säveltaso osoittaa; näin siis Hendrixin virityksen suhteen - muiden kitaristien ja muusikoiden osalta viritys voi mahdollisesti olla tietenkin mitä erilaisin.

(2) soundi:

Soundin kuvauksessa on käytetty kahta perussymbolia:

$$
\begin{aligned}
& \text { = soundin perusluonteen symboli. } \\
& \text { = elektronisen lisälaitteen symboli. }
\end{aligned}
$$

Seuraavassa luettelossa selvennetään näiden kahden perussymbolin yhteydessä käytettyjä lyhenteitä ja numerointia: 
N = Normal sound; ei lisälaitteita eikä juurikaan putkivahvistimesta aiheutuvaa äänen säröytymistä. (Kuten tunnettua äänen säröytyminen erottaa putkivahvistimen ja transistorivahvistimen toisistaan. Ks. esim. Levon 1983, 20-21.)

Nd = Normal sound with distortion; äänen säröytyminen eli "putkisärö" on selvästi havaittavissa. Numeroasteikko 1-5 kuvaa äänen säröytymisen astetta: 1 = vain hiukan säröä, 2 = selvästi säröytynyt, $3=$ paljon säröä, $4=$ hyvin paljon säröä, $5=$ äärimmäisen säröytynyt.

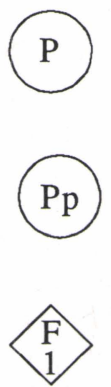

$=$ Phased; vaiheensiirros.

Pp = Phased with panning; vaiheensiirros ja panorointia.

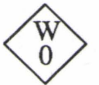

= Wah-Wah; numeroasteikko 0-5 kuvaa "poljentoa" eli miten ko. lisälaitetta on käytetty: $0=$ ei varsinaisesti "poljentoa" mutta pienet sävymuutokset mahdollisia, 1 = vain vähän, 2 = jonkin verran, $3=$ paljon, $4=$ hyvin paljon, 5 = äärimmäisen paljon.

U = Univibe; Leslie -tyyppinen lisälaite.

Lukuisille markkinoilla oleville lisälaitteille on edellä esitettyihin esimerkkeihin pohjautuen suhteellisen helppo keksiä sopiva symboli ja mahdollisesti tarvittava numeroasteikko. 
(3) erilaiset soittotekniikat ja fraseeraustekniikat:

B $\quad$ Bend; venytys.

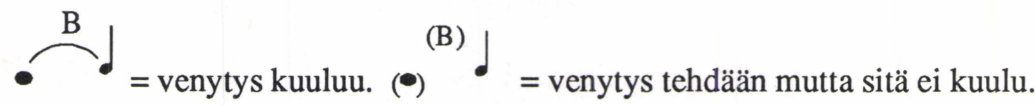

$\mathrm{B} / \mathrm{HB}=$ Bend/ Hold bend; venytys ja sen ylläpitäminen.

$\mathrm{B}_{\mathrm{S}} \quad=$ Bend slowly; hidas venytys.

$\mathrm{B}_{\mathrm{g}} \quad=$ Bend gradually; asteittaiseksi hahmottuva venytys.

$\mathrm{R} \quad=$ Release; venytyksen palautuminen, "vapautuminen".

$\mathrm{R}_{\mathrm{S}} \quad=$ Release slowly; venytyksen hidas palautuminen.

$\mathrm{R}_{\mathrm{g}} \quad=$ Release gradually; venytyksen asteittaiseksi hahmottuva palautuminen.

=n. 1/4 sävelaskelta merkittyä matalampi säveltaso.

=n. 1/4 sävelaskelta merkittyä korkeampi säveltaso.

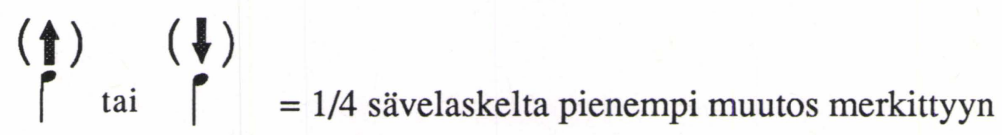
säveltasoon tai tulkinnanvarainen muutos.

$\mathrm{A} \sim \mathrm{=}=$ Arm; vibrakammella soitettuna

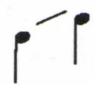

$=$ glissando. 
= legatofraseeraus liu'uttamalla; vain ensimmäinen sävel plektralla soitettuna.

$\llcorner\mathrm{T}$

d

X

$\mathrm{T} / \mathrm{P}$ harm.
$=$ Teeth; hampailla soitettuna .

= muted; sammutettu, "dempattu" sävel.

= muted chord; sammutettu sointu; ei välttämättä mikään varsinainen sointuote.

$=$ Thumb/Pick harmonics; peukalon ja plektran aikaansaamia yliääneksiä.

FB = Feedback; säveltasoltaan epämääräinen "kierto" = säveltasoltaan vakaampi feedback.

(4) muut merkinnät:

[ ] = sisältää soiton aikana tapahtuvaa verbaalista improvisointia.

\section{Esimerkit}

Seuraavassa tarkastelen kolmen esimerkin avulla edellä esittelemieni transkriptiomerkintöjen soveltuvuutta käytäntöön. Korvakuulolta tekemäni transkriptiot ovat Jimi Hendrixin kitarasooloista seuraavissa sävellyksissä: "Up from the skies" levyltä Bold as love (1968), "A merman I should turn to be / Moon turn the tides / Gently, gently away" levyltä Electric ladyland (1968) ja "The queen" levyltä In the west (1971). Tavoitteena ei tässä ole suinkaan analysoida kyseisiä sooloja, vaan esittää joitakin yleisiä huomioita ja mahdollisesti selventäviä kom- 
mentteja käytetyistä symboleista ja merkinnöistä - suurimman hyödyn transkriptioista saa tietenkin kuuntelemalla mainitut soolot levyltä.

Esimerkki 1: Up From The Skies

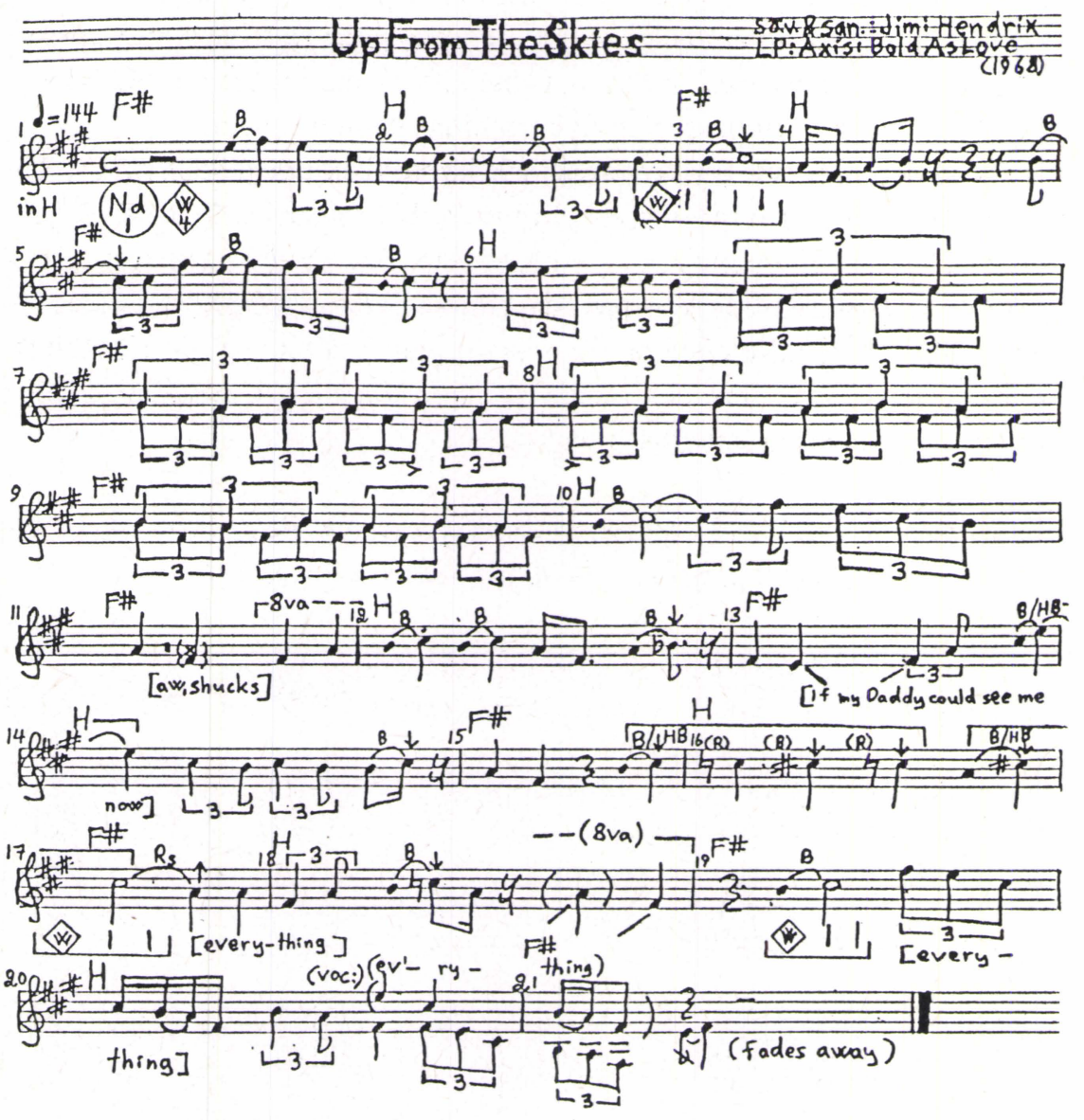

Soolon soundia hallitsee wah-wah-pedaali, jota on käytetty hyvin paljon - kitaran perussoundissa on havaittavissa vain hieman "putkisäröä". Wah-wah-pedaalin käytöstä on syytä huomata, että sitä on käytetty sointivärin muuntamisen lisäksi myös rytmisesti mielikuvituksekkaasti. Rytmisen elementin korostuminen tulee esille ensinnäkin tahtien 6-9 kompleksisessa rytmikuviossa, jota vielä muutamat aksentit rikastuttavat. Toinen rytminen oivallus liittyy venytyksiin: tahdeissa 3,17 ja 19 wah-wah-pedaalia on käytetty rytmisen perussykkeen korostamiseen pitkien aika-arvojen aikana; tällainen wah-wah-pedaalin käyttö etenkin 
kvartti-kvintti-venytyksen yhteydessä on erityisen tyypillistä Hendrixin improvisoinnissa.

Venytysten osalta ehkä mielenkiintoisinta on huomata tahdeissa 1517 tapahtuvat venytykset, joissa c:n ja cis:n säveltasoja on käsitelty vaihtelevasti. Tämäkin on tyypillinen piirre Hendrixin improvisoinnissa monilla muilla kitaristeilla on usein taipumus pitää säveltaso muuttumattomana heidän toistaessaan samaa venytystä useampia kertoja peräkkäin. Tahdissa 17 esiintyy myös venytyksen hidas palautuminen.

Sooloon sisältyy myös verbaalista improvisointia tahdeissa $11,13-$ 14 ja 17-20. Tämä improvisointi liittyy laulun tekstisisältöön ja on ymmärrettävissä siihen liittyvänä - olkoonkin että tämä maapallon ulkopuolisesta tarkkailijasta kertova tarina ei ole ehkä kaikkein helpposelitteisimpiä. Mielenkiintoista on huomata myös, että tahtien 17-20 verbaalinen improvisointi muuttuu tahdeissa 20-21 lauletuksi melodiaksi, joka liikkuu unisonomaisesti kitaran kanssa.

Esimerkki 2: 1983... (A Merman I Should Turn To Be) / Moon Turn the Tides...Gently, Gently Away

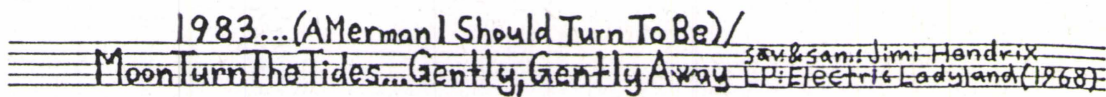
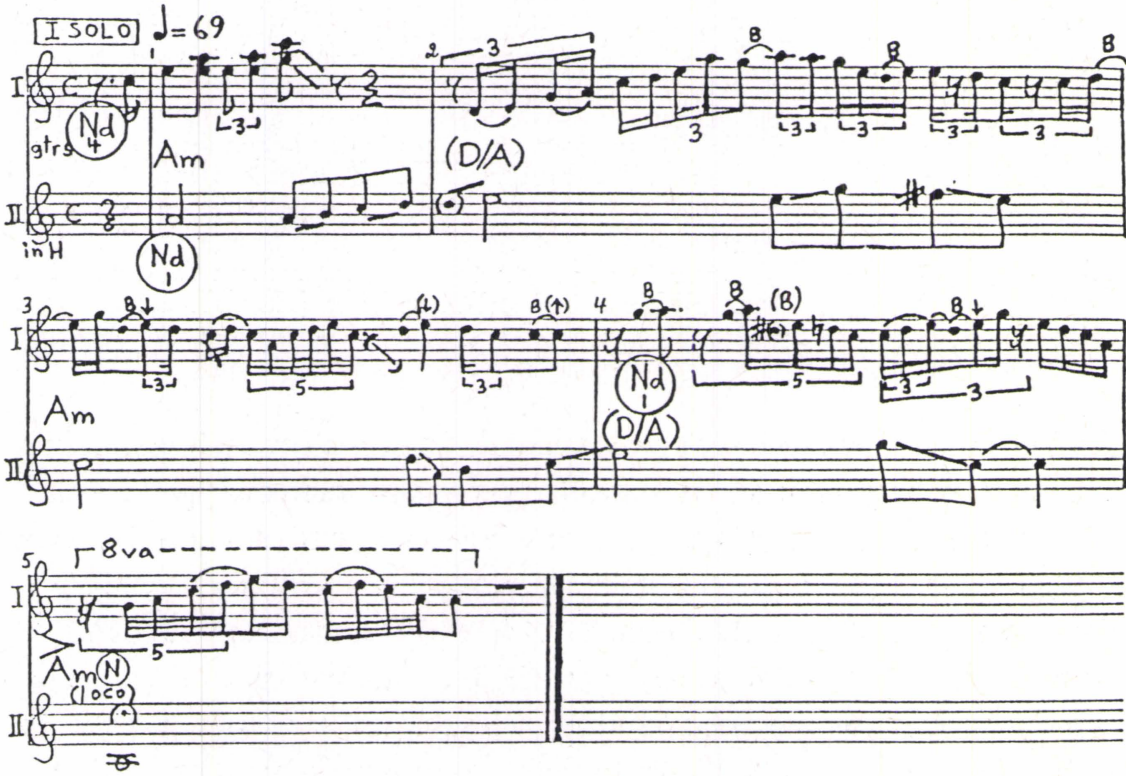
Kyseinen soolo on sävellyksestä, jota voidaan mielestäni pitää Hendrixin merkittävimpänä teoksena. Transkriptiossa alaääni edustaa teoksen instrumentaalista teemaa ja ylä-ääni improvisoitua sooloa. Melodista ja selkeälinjaista teemaa hallitsee soundi, joka syntyy glissandofraseerauksesta ja vain vähäisesta "putkisäröstä". Improvisoitu soolo sen sijaan alkaa erittäin säröytyneellä soundilla, joka kuitenkin myöhemmin "puhdistuu": ensin tahdissa 4 ja lopullisesti tahdissa 5, jossa soundissa ei juurikaan ole enää "putkisäröä" - vaikutelmaa vahvistaa myös saman tahdin diminuendo. Venytyksistä on syytä huomioida tahdin 4 venytys dis-e, joka edellisen venytyksen g-a yhteydessä tehdään, mutta joka ei varsinaisesti kuitenkaan kuulu.

Esimerkki 3. The Queen
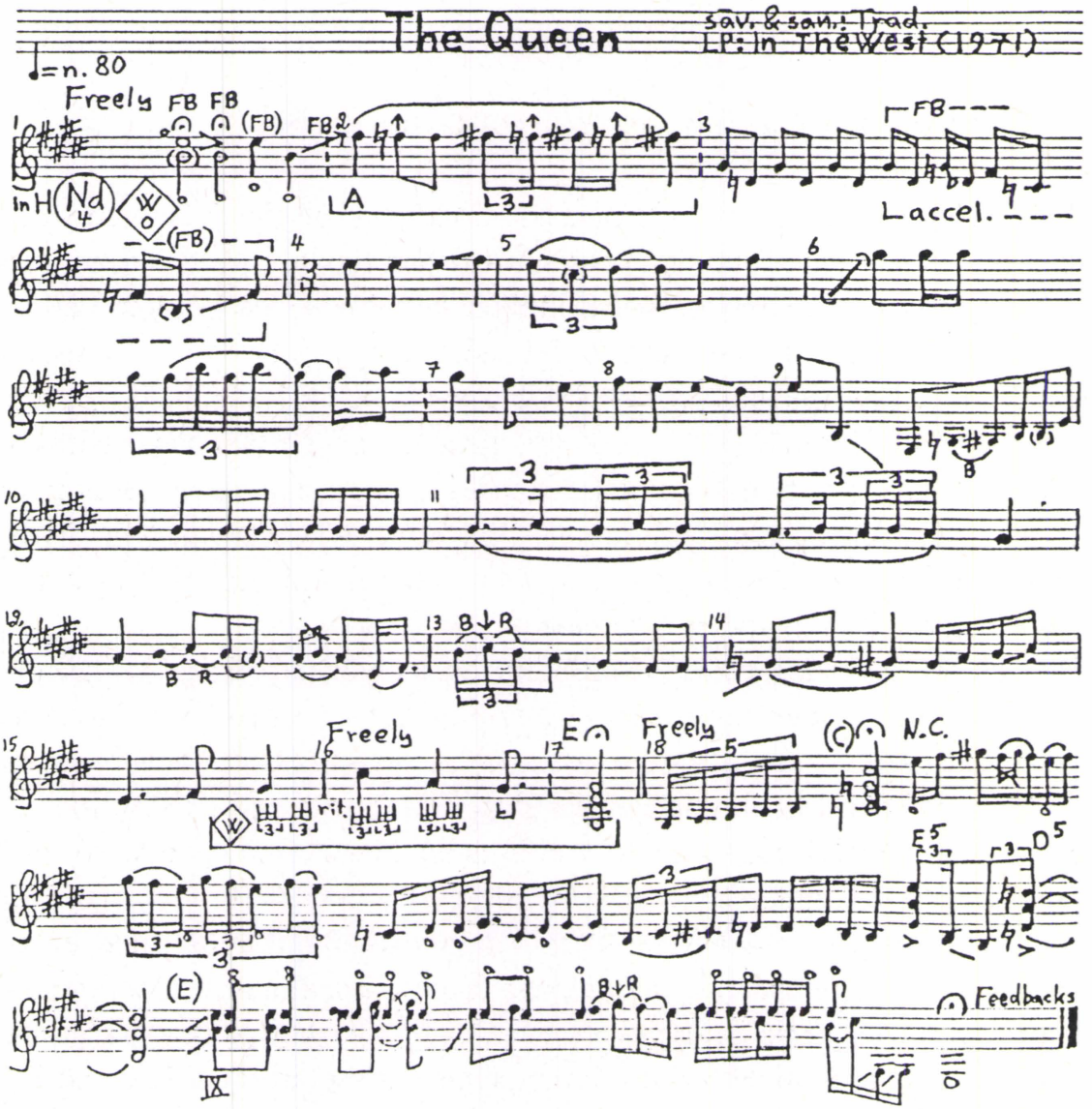
Hendrixin versiot Englannin ja Yhdysvaltojen kansallislauluista ovat rockmusiikin klassikoita, ja niiden merkitys tulee säilymään tulevaisuudessakin. Esimerkin versio Englannin kansallislaulusta on tallennettu konserttitilanteesta.

Soundiensa puolesta esitykseen sisältyy mielenkiintoisia piirteitä. Ensinnäkin erittäin säröytyneeseen soundiin yhdistyy wah-wah-pedaalin säästeliäs käyttö - teeman lopussa eli tahdeissa 15-17 wah-wah-pedaali on tosin keskeisesti esillä. Toiseksi eri jaksoilla on oma soinnillinen luonteensa: aloitusjaksoa (t. 1-3) dominoivat vibrakammella kontrolloidut vapaiden e- ja h-kielten feedback-sävelet - tritonukset lisäävät alun raivoisuutta, teemalle (t. 4-17) puolestaan antaa oman sävynsä legato- ja glissandofraseeraus, ja lopetusjakson (t. 18) soinnillinen ominaispiirre syntyy vapaiden kielten runsaasta käytöstä. Venytysten vähäinen määrä korostaa melodian keskeistä roolia tulkinnassa.

\section{Transkriptiomerkintöjen soveltuvuudesta}

Esitettyjen transkriptiomerkintöjen käyttökelpoisuudesta ja soveltuvuudesta voidaan todeta, että niiden avulla voidaan tuoda esille sähkökitaran perinteisesti keskeisimmät soittotekniikat ja soundit - koko ajan keksitään tietenkin uusia soittotekniikoita ja soundeja, jotka vaativat usein myös uusia merkintätapoja. Soundien kuvaaminen esittelemieni symbolien avulla helpottaa sekä soundimuutosten visuaalista hahmottamista että moniäänisten transkriptioiden seuraamista ja eri äänten hahmottamista itsenäisiksi ääniksi. Symbolien käytön avulla saavutetaan myös transkriptioita tehtäessä johdonmukainen asennoituminen kaikkiin kuultaviin soundeihin ja niiden muutoksiin.

Transkriptioiden tekemiseen liittyy aina myös subjektiivista tulkintaa - transkriptiomerkinnöissäni esimerkiksi numeroasteikon valinnan ja mikrointervallien merkitsemisen suhteen. Lopputuloksen kannalta subjektiivinen näkemys on mielestäni kuitenkin parempi valinta kuin jonkin keskeisen musiikillisen tekijän vaillinainen kuvaaminen tai kokonaan kuvaamatta jättäminen.

Tulevaisuudessa afroamerikkalaisen musiikin tutkimus tulee epäilemättä voimistumaan ja muuttumaan laaja-alaisemmaksi. Rockmusiikin, bluesin ja jazzin analyyttinen tutkimus on tuskin päässyt kunnolla alkamaan, kun jo uudet tyylisuuntien synteesit asettavat uusia haasteita ja tutkimuskohteita tutkijoille. Tällä artikkelilla toivon antaneeni joitakin 
ideoita pohdittavaksi ja sovellettavaksi musiikintutkimuksessa joko sellaisinaan tai sitten muunneltuina sopimaan paremmin kulloiseenkin käyttötarkoitukseen.

\section{Lähteet}

Brolinson, Per Erik \& Larsen, Holger

1981 Rock... Aspekter på industri, elektronik \& sound. Falköping.

Emblidge, David Murray

1973 A dialogue of Energy: Rock Music and Cultural Change. University of Minnesota, Ph.D. 1973 Music.

Henderson, David

1983 The Life of Jimi Hendrix. 'Scuse me while I kiss the sky. New York: Bantam Books. Condensed and rev. from Jimi Hendrix: voodoo child of the Aguarian age. Garden City, N.Y.: Doubleway, 1978.

Hood, Mantle

1982 The Ethnomusicologist. New Edition. Kent, Ohio. Knight, Curtis

1975 Jimi Hendrix. An Intimate Biography of Jimi Hendrix. Suffolk.

Levo, Antti

1983 Kitaramöykän perustiedot. Soundi 1983:3.

Menn, Don

1978 The Equipment of Jimi Hendrix... Teoksessa Rock

Guitarists, Volume II. Toim. Jerry Martin. New York.

Neal, Peter

1968 The Experience -elokuva.

Sandner, Wolfgang

1977 Sound \& Equipment. Teoksessa Rockmusik. Aspekt zur

Geschickte, Ästhetik, Produktion. Toim. Wolfgang

Sandner. Mainz.

Savola, Ismo

1989 Jimi Hendrixin maailmankuva ja musiikkikäsitteistö. Musiikkitieteen pro gradu -tutkielma, Jyväskylän yliopisto, musiikkitieteen laitos. 
Schneider, John

1985 The Contemporary Guitar. Berkeley and Los Angeles: University of California Press.

Wein, Chuck

1970 Rainbow Bridge -elokuva. 